\title{
Influence of shungite treatment methods on its absorption properties and on water treatment quality for beverages production
}

\section{Svitlana Oliynyk ${ }^{1}$, Lyudmila Mel'nyk ${ }^{1}$, Iryna Samchenko ${ }^{1}$, Natalia Tkachuk ${ }^{1}$, Olga Loginova ${ }^{2}$, Ludmyla Kisterska ${ }^{2}$}

\author{
1 - National University of Food Technology, Kyiv, Ukraine \\ 2 - V. Bakul Institute of Superhard Materials, National Academy of Sciences of Ukraine, \\ Kyiv, Ukraine
}

Keywords:

Water

Treatment

Shungit

Absorption

Nanosilver

Article history:

Received

11.04.2019

Received in revised

form 18.09.2019

Accepted

28.11.2019

Corresponding

author:

Natalia Tkachuk

E-mail:

tkachuk2008@

bigmir.net

DOI:

$10.24263 / 2304-$

974X-2019-8-4-18

\section{Abstract}

Introduction. The prospect of treating shungite in various ways to increase its absorption properties and increase the efficiency of water treatment during beverage production is shown.

Materials and methods. Drinking water was prepared using shungite activated, activated and modified by nanosilver, activated, steam treated and modified by nanosilver. Photometric, spectrometric, chemical and potentiometric methods of analysis, theoretical generalization and comparison, a systematic approach were used in the work.

Results and discussion. The parameters of aggregation of nanoparticles in water-glycerol medium, adsorption and sorptioncatalytic properties of shungite activated and nanomodified in various ways are investigated.

Additional treatment of activated shungite with steam and nanosilver allows to increase its adsorption activity for iodine and for adsorption of acetic acid, alkalinity of water infusion up to 1.2 times and to provide stabilization of the redox potential of the prepared water at the level of $+90-100 \mathrm{mV}$.

Steam treatment enhances part of the pores before diffusion and molecular sorption, and increases the adsorption activity of humic and fulvic acids by $40 \%$ by activated steam and silver nanoparticles by $40 \%$.

Waste water costs during the preparation of activated steam and nanosilver shungite do not exceed 20 relative volumes of wash water per volume of material, allowing the transparency of the prepared water is at least $99 \%$.

Pre-treatment shungite of steam before its activation with silver nanoparticles due to improving the wetting of the surface makes it possible to increase the duration of the filter cycle and the possibility of deepening the sorption of harmful water impurities: iron, manganese, nitrogen and organic compounds by $10-12 \%$.

Conclusions The use of shungite activated steam treated and modified by nanosilver provides increased efficiency of cleaning of harmful impurities and stabilization of the redox potential of the prepared water. 


\section{Introduction}

The production of beverages involves the use of high quality prepared water, which has additional requirements that are related to the peculiarities of the technology of preparation, shelf life and finished product destination [1]. The use of silver instead of the harmful chemicals (fluorine, chlorine and chlorine-containing compounds) makes water not only safe (it has been proved [2] that silver ions kill the vast majority of harmful microorganisms) but also beneficial as in absence of harmful microorganisms the color, smell and taste of water is much better [3].

Nowadays considerable scientific and applied interests are the possibility of using effective natural adsorbents in water purification processes [4]. One of the most promising materials is shungitis [5]. Shungite is a natural material-a rock that has the composition similar to anthracite and graphite [6]. The use of shungite in water treatment as a filter material is due to its high adsorption capacity [7], corrosion resistance [8], catalytic activity [9], low cost [10], ecological purity and safety [11]. The main properties of shungite are described in [12-15]. Mosin O. [6,8,16], Mel'nyk L. [7], Mukhin V. [17], Wang S. [18], and other researchers have shown the prospect of using shungite as a filter material in water treatment for the food industry [19,20], in different types of soft drinks production [21,22] and established the efficiency of purification from mineral impurities [7].

During the vodka preparation it was proposed to use a method of purifying water by sequential filtration through shungite and zeolite, followed by passing through a column of shungite. According to the authors, "the presence of shungite in the charge of the zeolite leads to a decrease in the alkalinity of water and the transition of $\mathrm{pH}$ to the neutral acid part", which increases the tasting evaluation of finished products [8].

Recently, more and more attention is being paid to water treatment methods that would help stabilize the water oxidation-reduction potential [24].

The method of metal cathode dispersing by the localized glow discharge in vacuum has developed an innovative one-stage combined "wet-dry" technology for the production of concentrated colloidal solutions of nano metals in liquid media of different physical and chemical nature, which allowed to create ready-to-use nanosilver suspension in food glycerol. The undeniable advantages of high-purity nanosilver, physically implanted into food glycerol and stabilized in it without additional chemical reagents, are exceptionally low toxicity to humans and animals along with high bactericidal properties, the method demonstrate high industrial productivity and a competitive price in comparison to European and world analogs [26].

The studies aimed at the simultaneous regulation the water oxidation-reduction potential and the harmful impurities removal are especially important [27]. Thus, research aimed at using natural shungite modified by nanosilver for water treatment technologies is necessary and relevant.

The provided studies were concentrated of water oxidation-reduction potential change true nature and the quantitative characteristics of the water preparation during its sorption purification using shungite treated in various ways: activation; treatment with nanosilver, without it and with steam pre-treatment. The main tasks of the research were: determination of the adsorption and sorption-catalytic properties of the shungite treated in various ways to stabilize the of water oxidation-reduction potential, the efficiency of its purification from high- and low-molecular organic compounds and toxic substances, compliance with the requirements of current regulatory standards for soft beverages. 


\section{- Processes and Equipment -}

\section{Materials and methods}

\section{Materials under study}

1. Drinking water of the Kyiv Artesian well and treated water,

2. Naturally activated specimens of shungite of the Zagozhin deposit (1.0 mm fraction).

\section{Preparation of prototypes}

Activation of natural shungite was carried out at a temperature of $150-180{ }^{\circ} \mathrm{C}$ during 2 hours. Further $100 \mathrm{~g}$ of the appropriate sample of shungite was loaded into a glass column, washed with distilled water to achieve the filtrate transparency at least $98 \%$ [15].

The modification of shungite by nanosilver was carried out by adsorption from solutions after sieving without pre-washing with distilled water and after pretreatment with the appropriate steam sample. The silver nanosuspension produced using ion-plasma technology at a pilot plant was used to modify the shungite. A detailed description of the methodology and installation for silver nanosuspension manufacturing is given in article [25].

To study the state and parameters of nanoparticle aggregation in aqueous-glycerol medium, the resulting suspension was irradiated with a helium-neon laser with $X=633 \mathrm{~nm}$, scattered light which was recorded at an angle of $173^{\circ}$ [28]. The absorption spectra were measured in a cuvette $(1 \mathrm{~cm})$ before and after ultrasound. Distribution of silver nanoparticles in solution before and after treatment and in triplicate repetition with different nanoparticle concentration was defined by laser photon correlation spectroscopy [28] on Zeta Sizer Nano $\mathrm{S}$ instrument (Malvern, UK) at $25{ }^{\circ} \mathrm{C}$. The kinematic viscosity of the suspensions required to calculate the nanoparticle size distribution was measured on a Malvern SV-10 (Japan) vibration viscometer [28].

To evaluate the stability of the formed silver agglomerates in glycerol, the distribution of silver nanoparticles in solution before and after ultrasonic treatment and in three-fold repeatability with different nanoparticle concentrations was investigated [28]. Marking of the samples was as follows: 1.0-initial suspension of silver nanoparticles in glycerol, 1.1-diluted suspension in 2 times, 1.2-diluted suspension in 10 times.

\section{Procedure of research conducting}

Water filtration was carried out at temperatures from 18 to $22{ }^{\circ} \mathrm{C}$ in dynamic mode for three glass filters with a diameter of $50 \mathrm{~mm}$. Each filter was filled up with a corresponding sample of shungite layer with a height of $500 \mathrm{~mm}$ each.

The process of sorption purification of water included the preparation of the material for operation, such as pre-washing before the filter cycle and the basic filter cycle.

Preparation of the material for work, the main filtering cycle through an appropriate sample of shungite was carried out by gravity from top to bottom of the filter at a speed of $10-12 \mathrm{~m} / \mathrm{h}$. Organoleptic and physic-chemical parameters of the prepared water were determined after every $500 \mathrm{~cm}^{3}$ of the filtrate.

\section{Description of methods}

During the research, the adsorption characteristics of the shungite samples were determined by the methods used during the incoming control in the hard liquors distillery: total pore volume for water [29], adsorption activity for: iodine [29], alkalinity of water 
infusion and adsorption of acetic acid [29], acid-base properties of water infusion and humic and fulvic acids [29].

Studies of water quality before and after its purification with a suitable sample of shungite were performed:

- Colorimetric method using the photoelectric colorimeter KFK-2 in determining the mass concentration of iron, manganese, nitrogen-containing substances [29],

- Spectrophotometric method (spectrophotometer Specord UV) in determining transparency [29, 30];

- Permanganometric method for determining permanganate oxidation [29],

- Potentiometric ( $\mathrm{pH}-$ meter + ORP-meter $\mathrm{pH}-099$ and $\mathrm{pH}-150 \mathrm{MI}$ ) when determining the redox potential $[31,32]$.

Determination of water purification efficiency by a suitable sample of shungite was carried out by spectrophotometric method in the ultraviolet region of the spectrum at a wavelength of 200-350 $\mathrm{nm}$ and a cuvette of length $\mathrm{S}=50 \mathrm{~mm}$ [29].

\section{Processing of research results}

Experimental, mathematical and statistical methods were used in the work-planning and processing of experimental results. The research results were systematized and processed using mathematical and statistical methods on the basis of modern software [29-31].

\section{Results and discussion}

\section{Aggregation parameters of nanoparticles in aqueous-glycerol medium}

Absorption spectra of solutions of silver nanoparticles in glycerol before and after ultrasonic treatment during $10 \mathrm{~min}$. is given in Figure 1. As shown on Figure 1, the data shows that the solution absorption spectra retain their shape during the dilution, ie dilution of the solution with water does not lead to structural changes in the sample.

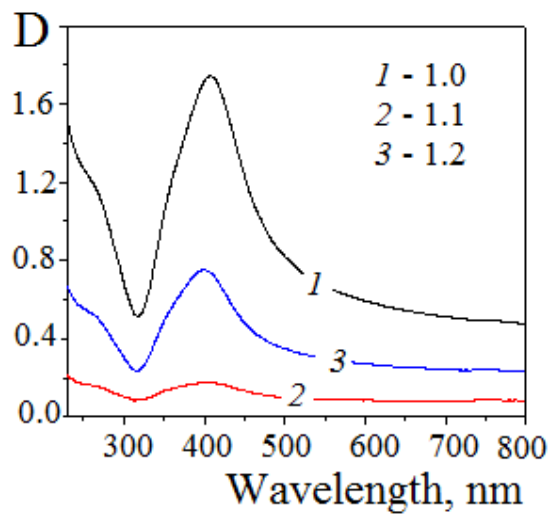

$a$

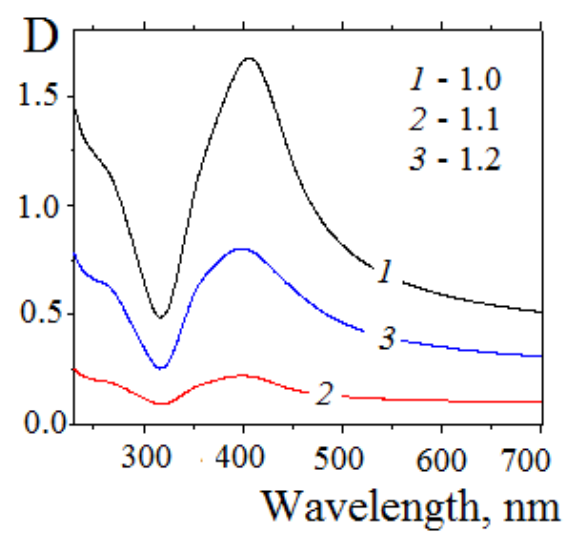

$\boldsymbol{b}$

Figure 1. Absorption spectra of silver nanoparticles solutions in glycerol before (a) and after (b) ultrasonic treatment. 
The distribution of silver nanoparticles before and after ultrasonic treatment is presented in Figure 2. As can be seen from Figure 2, the distribution of silver nanoparticles by size after ultrasonic treatment changes in the direction of a significant reduction in the size of agglomerates formed in solution (from almost 200 to $60 \mathrm{~nm}$ ), that is, ultrasonic treatment of nanosilver solutions actively destroys agglomerates. This is the result we obtained earlier in article [26].

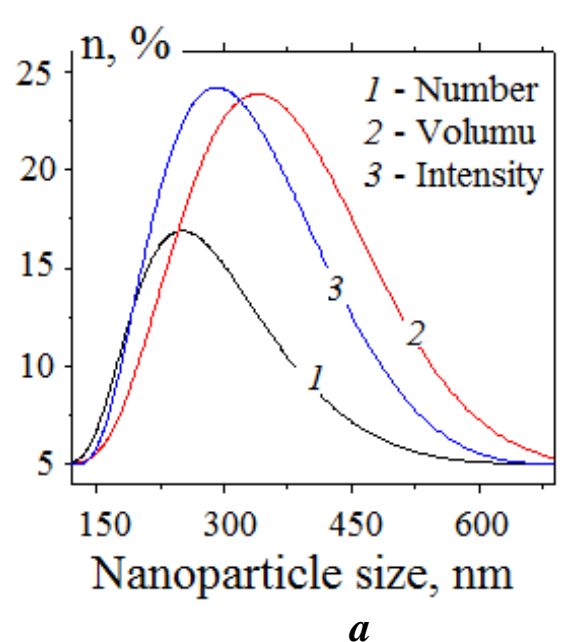

Figure 2. Distribution of silver nanoparticles in solution before (a) and after (b) ultrasonic treatment.

It is known that the aggregate stability of colloidal solutions (sols) is proportional to the charge of the colloidal particle, which is determined by the electrokinetic potential $(\xi$ potential). The $\xi$-potential arises on the slip plane of the double electric layer due to the separation of its diffuse part from the adsorbed bound fixed part, it determines the charge of the diffuse layer and is a measure of the intensity of electrokinetic phenomena in the interfacial region. The sign and value of the $\xi$-potential are widely used to characterize the electrical properties of a surface when considering adsorption, adhesion, aggregate stability of dispersed systems, structure formation in materials and in other processes where electrokinetic phenomena exist. The larger the $\xi$-potential of the system, the greater the value of the average electric charge of the colloidal particles. The presence of colloidal particles of the same charge leads to their mutual repulsion, preventing the possible sticking (agglomeration, aggregation) of the particles of the dispersed phase, informing the system of the aggregate stability.

The values of the size of silver nanoparticles and $\xi$-potential in the given suspensions are presented in Table 1. As can be seen from the data in Table 1, the aggregate stability of the original solution and diluted with water is stored at the level of $30-70 \mathrm{mV}$, ie after ultrasonic treatment, these solutions were stable at different dilutions. For theoretical limit of colloidal systems stability, the value of $\xi$ - potential greater than $30 \mathrm{Mv}$ is assumed [32,37]. 
Table 1

Value of the $\xi$-potential $(\mathrm{mV})$ of silver nanoparticles in solutions

\begin{tabular}{|c|c|c|}
\hline Sample & $\begin{array}{c}\text { The value of the } \boldsymbol{\xi} \text {-potential } \\
\text { before ultrasonic treatment, } \\
\mathbf{m V}\end{array}$ & $\begin{array}{c}\text { The value of the } \boldsymbol{\xi} \text {-potential } \\
\text { after ultrasonic treatment, } \\
\mathbf{m V}\end{array}$ \\
\hline 1.0 & $-65,2$ & $-74,3$ \\
\hline 1.1 & $-11,5$ & $-29,1$ \\
\hline 1.2 & $-51,5$ & $-56,9$ \\
\hline
\end{tabular}

\section{Sorption capacity of activated and modified nanosilver shungite}

High-quality sorption-filtering material that can be used in water purification systems from high- and low-molecular-weight organic compounds and toxic substances for the soft drinks production should have high adsorption, sorption-catalytic properties, in addition to the optimal structure (Table 2).

The data shown in Table 2 proved that the modification of shungite by silver nanoparticles makes it possible to increase the total pore volume of water and the total volume of basic oxides by 1.2 times, thereby increasing its adsorption activity: iodine and acetic acid adsorption by 1.3 times, the alkalinity of the water infusion- 2.0 times, which will contribute to a longer filter cycle and the possibility of in-depth sorption of harmful water impurities.

Table 1

Adsorption and sorption-catalytic properties of shungite treated in various ways

\begin{tabular}{|c|c|c|c|}
\hline \multirow[t]{2}{*}{ Indicator name } & \multicolumn{3}{|c|}{ Indicator value for shungite sample } \\
\hline & Activated & $\begin{array}{l}\text { Activated and } \\
\text { modified by } \\
\text { nanosilver }\end{array}$ & $\begin{array}{c}\text { Activated, } \\
\text { Steam treated and } \\
\text { modified by nanosilver }\end{array}$ \\
\hline $\begin{array}{l}\text { Total pore volume by } \\
\text { water, } \mathrm{cm}^{3} / \mathrm{g}\end{array}$ & 0,45 & 0,55 & 0,6 \\
\hline \multicolumn{4}{|l|}{$\begin{array}{l}\text { Total amount of } \\
\text { oxides, } \mathrm{mol} / \mathrm{m}^{3} \text { : }\end{array}$} \\
\hline- acid & 0,3 & 0,32 & 0,35 \\
\hline- basic & 0,4 & 0,5 & 0,7 \\
\hline \multicolumn{4}{|l|}{ Adsorption activity by: } \\
\hline- iodine, $\%$ & 45 & 57 & 65 \\
\hline $\begin{array}{ll}- & \text { alkalinity of water } \\
\text { infusion, } \mathrm{cm}^{3}\end{array}$ & 2,5 & 5,0 & 5,8 \\
\hline $\begin{array}{l}- \text { adsorption of } \\
\text { acetic acid, } \mathrm{cm}^{3}\end{array}$ & 40 & 55 & 62 \\
\hline
\end{tabular}


Pre-treatment with steam indicates the positivity of its application to the main stage of modification of shungite by nanosilver, resulting in an increase: total pore volume by 1.2 times, total volume of basic oxides by 1.4 times, indicators of adsorption activity for iodine, alkalinity of aqueous infusion and adsorption of acetic acid by 1.1-1.2 times. This is proved by the studies shown by us in article [7], that is, the adsorption activity of the steam-treated shungite increases by improving the wetting of the surface with aqueous solutions.

The presence of humic acids and fulvic acids significantly impairs the organoleptic characteristics of prepared water [1], so it was necessary to determine the adsorption activity for these substances. Figure 3 presents the adsorption activity of the samples by humic acids and fulvic acids. It is confirmed that, compared to activated shungite, the adsorption activity of nanosilver-treated shungite is higher by $25 \%$, the adsorption activity of steam-treated and nanosilver-treated is higher by $40 \%$.

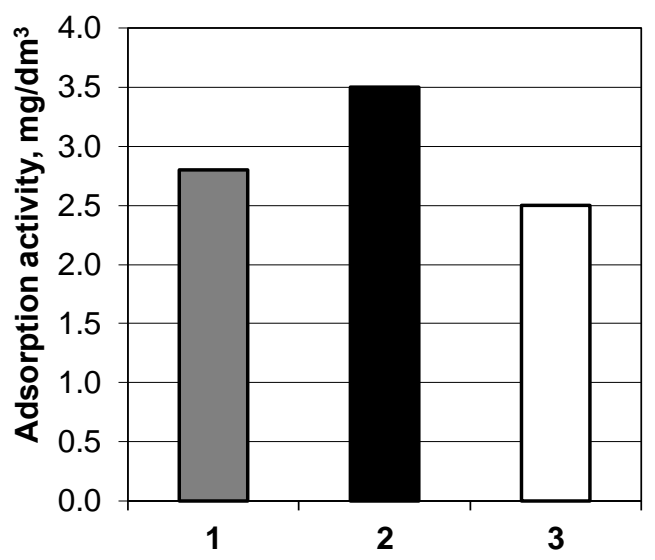

Figure 3. Shungite samples adsorption activity on humic and fulvic acids:

1 - shungite sample activated and modified by nanosilver;

2 - shungite sample activated, steam treated and modified by nanosilver; 3 - shungite sample activated.

This is due to the fact that the adsorption of humic and fulvic acids on shungite is carried out on the surface of the pores of the material, the effective diameter of which exceeds the size of their molecules contained in the solution. Thus, most of the pores treated with steam and treated with nanosilver are available in size for the diffusion of humic acid molecules, the absorption of humic and fulvic acids, as well as their salts, which is provided due to molecular sorption, as that was confirmed by the data obtained from carbonaceous materials [39].

The effectiveness of shungite samples washing at the stage of preparation for work was evaluated by the transparency indicator, which should not be less than $99 \%$, according to the requirements of the current regulatory documents [1]. The analysis of the obtained data shows (Figure 4) that the consumption of flushing water at the stage of shungite preparation, to achieve standardized water transparency of $99 \%$ for shungite treated with steam and nanosilver is rising to 20 relative volumes of flushing water per volume of material. For activated shungite and nanosilver-treated shungite, there is an increase in the cost of flushing water, which will negatively affect the resource costs of production and will increase the cost 
of water treatment, which was confirmed by other researchers [1,4]. It is possible to conclude from the given data that to reduce the consumption of flushing water at the preparatory stage, before further processing of shungite with silver, shungite must be activated and treated with steam.

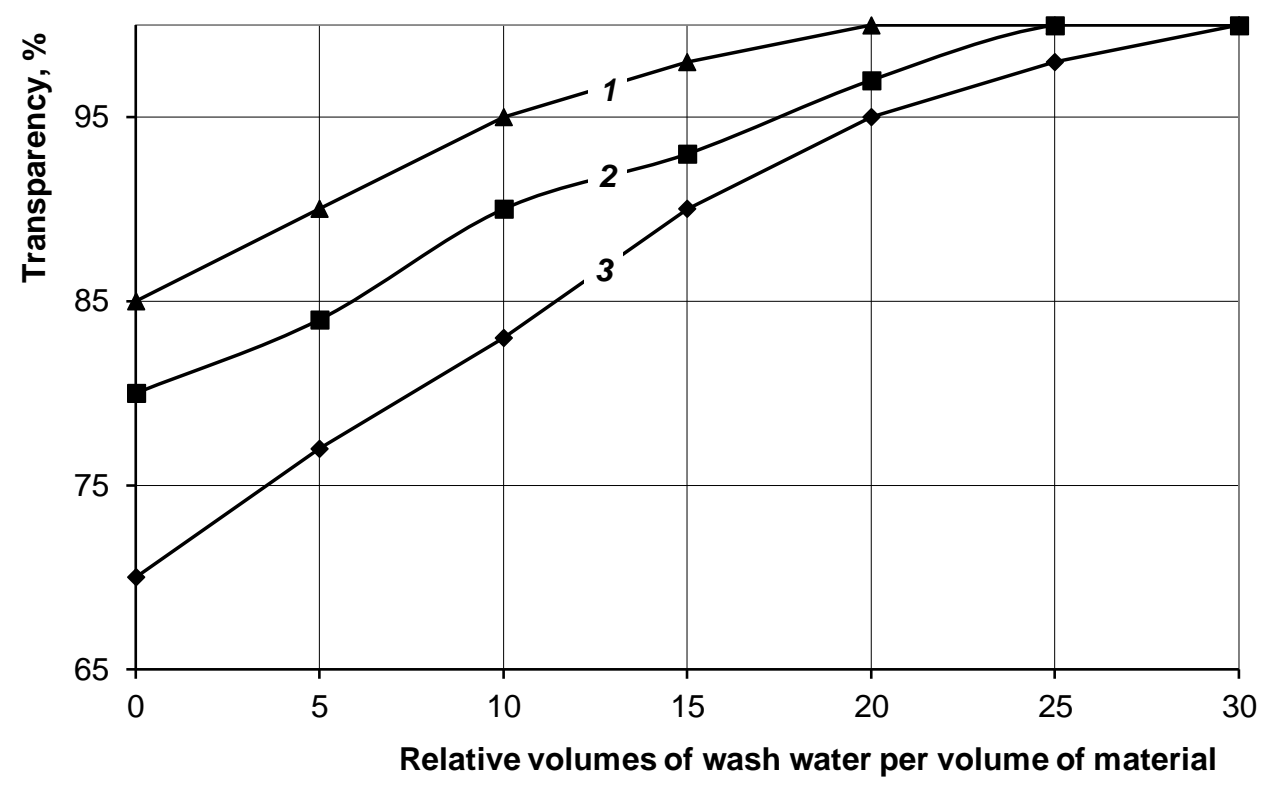

Figure 4. The consumption of flushing water at the stage of shungite preparation:

1 - shungite sample activated, steam treated and modified by nanosilver;

2 - shungite sample activated;

3 - shungite sample activated and modified by nanosilver.

During the production of beverages, a particular attention is paid to the value of permanganate oxidation, which characterizes the content of organic compounds in the prepared water, as well as the efficiency of water purification from iron, manganese and nitrogen-containing compounds (Figure 5) [1]. The effect of water purification from impurities of iron, manganese, nitrogen and organic compounds is higher by $10-12 \%$ when using a sample of shungite, which was activated, treated with steam and nanosilver, which is explained and confirmed by its better adsorption properties.

The properties of water are determined by its micro- and macro-component composition, as well as by its structure [1]. Prepared water, unlike natural water, has no pleasant refreshing effect, fullness of taste, characterized by disordered structure [23]. 


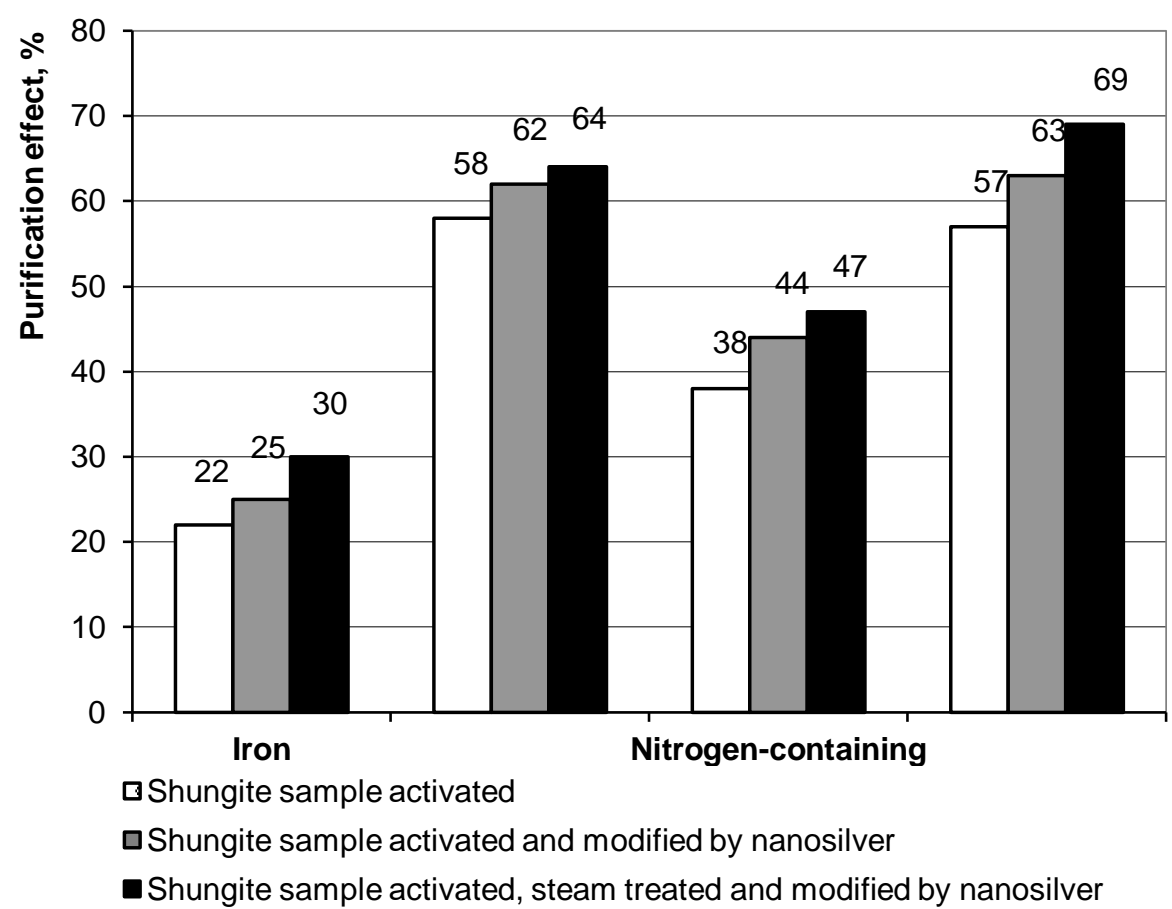

Figure 5. Efficiency of water purification using shungite treated in various ways

In modern conditions of production and consumption of different types of beverages (alcoholic and nonalcoholic), not only their chemical composition but also the physical indicators of beverages, which directly influence the processes of ensuring human life, are of particular importance [33]. One such indicator is the water oxidation-reduction potential [34]. This indicator of water characterizes the degree of activity of electrons in redox reactions indicates the biological activity and antioxidant property of water [35].

Regulatory documents that set requirements for the quality of drinking water and prepared value of the water oxidation-reduction potential is not regulated. In natural water, without its additional technological treatment, the value of the water oxidation-reduction potential varies widely from $-400 \mathrm{mV}$ to $+700 \mathrm{mV}[33,34]$. However, during water treatment the water oxidation-reduction potential increases to $+200-+400 \mathrm{mV}[33,34]$. In order to achieve a positive technological effect with the maximum preservation of natural properties and physicochemical characteristics of water, the influence of shungite treated in various ways the water oxidation-reduction potential was investigated (Figure 6).

The results obtained indicate a gradual decrease the water oxidation-reduction potential of the prepared water from $+250 \mathrm{mV}$ and the achievement value of $+70 \mathrm{mV}$ on the seventeenth volume of the prepared water to the volume of the shungite treated with nanosilver; for steam and nanosilver treated shungite the water oxidation-reduction potential reaches $+40 \mathrm{mV}$. In the further prepared water volume there is an increase of the index of the water oxidation-reduction potential and its stabilization at the values of $+150-170 \mathrm{mV}$ during the treatment of shungite with nanosilver, $+90-100 \mathrm{mV}$-during the treatment of shungite with steam and nanosilver. 


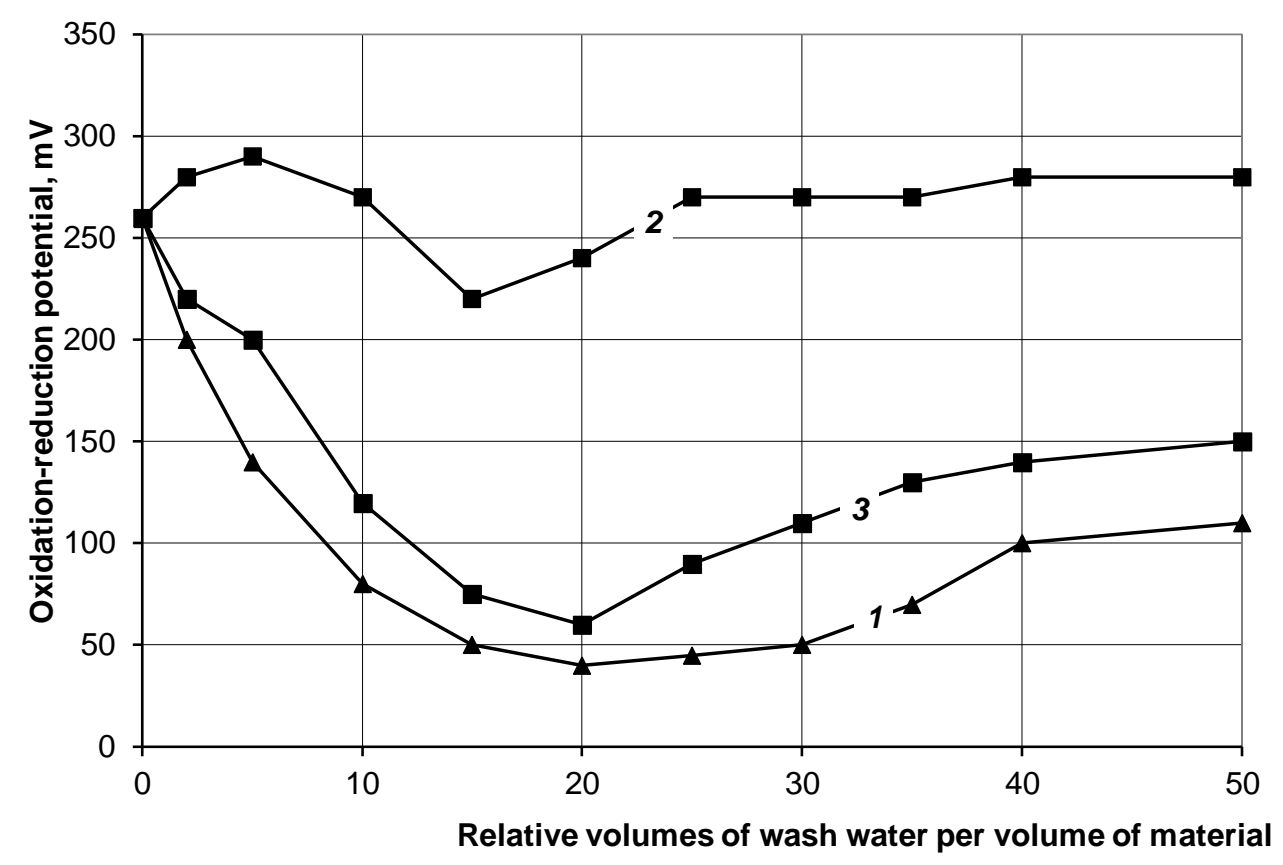

Figure 6. Water oxidation-reduction potential of the prepared water using activated shungite, activated and treated by nanosilver shungite, activated, steam and nanosilver treated shungite.

Thus, the use of shungite treated with steam and nanosilver is effective for stabilizing the water oxidation-reduction potential, which is confirmed by the acquisition of water antioxidant properties [35]. The additional decrease of the water oxidation-reduction potential of water prepared by shungite treated with steam and nanosilver from +70 to +40 $\mathrm{mV}$ can be explained by the presence of a negative charge of nanoparticles on the surface, as evidenced by the value of the $\xi$ potential [25].

\section{Conclusions}

The urgency of shungite treated in different ways use for water purification in the production of different types of beverages is substantiated. The most effective method to increase the adsorption activity of the material, to reduce the consumption of flushing water during shungite preparation to the filter cycle, to stabilize the redox potential of the treated water is the preliminary preparation of the shungite, which includes activation, steam and nanosilver treatment.

The use of nanomodified and steam-treated shungite is effective for stabilizing the redox potential of the material, indicating the acquisition of water antioxidant properties. 


\section{References}

1. Kuzmin O., Topolnyk V., Loviagyn A., Kuzmyn V. (2011), Vodka: technology, quality, innovation, Donetsk., DonNUET.

2. Landsdown Alan BG (2006), Silver in healthcare: Antimicrobial effects and safety in use. Curr Probl Dermatol. 33, pp. 17-34.

3. Kibardin G. (2010), Shungit i ego celebnie svoistva, Moscow, Amrita-Rus.

4. Ryabchikov B. (2013), Sovremennaya vodopodgotovka [Modern Water Preparation], Moscow.

5. Mosyn O., Yhnatov Y. (2015), Research of Influence of Shungite on Mountain Water from Bulgaria. Mathematical Models of Water Influenced from Shungite and Zeolite, Journal of Medicine, Physiology and Biophysics, 12, pp. 1-19.

6. Mosyn O., Yhnatov Y. (2013), Sostav y strukturne svoistva pryrdnoho fulerenosoderzhashcheho mynerala shunhyta, Byotekhnosfera, 1(25), pp. 29-33.

7. Mel'nik L., Tkachuk N., Turchun O., Diyuk V., Ishchenko O., Byeda O., Kisterska L., Loginova O., Lysovenko S., Gontar O., Garashchenko V. (2017), Adsorption properties of shungite in purification of water-alcohol solutions, Journal of Superhard Material, 39(6), pp. 416-421, DOI: 10.3103/S1063457617060053

8. Mosin O., Ignatov I. (2013), The structure and compositions of natural carbonaceous fullerene containing mineral shungite, International Journal of Advanced Scientific and Technical Research, 3(11), pp. 9-21.

9. Kulikova V. (2006), Treatment shungite, Moscow.

10. Mosyn O. (2011), Novyi pryrodnyi myneralnyi sorbent - shunhyt, Santehnika, 3, pp. 34-36.

11. Musyna U. (2014), Koksuevskye shunhytystye porody v protsessakh obespechenyia ekolohycheskoho ravnovesyia, Yzvestyia Sankt-Peterburhskoho hosudarstvennoho tekhnolohycheskoho ynstituta, 23(49), pp. 79-82.

12. Pushmyna Y., Khorunzhyna S., Permiakova L. (2009), Yspolzovanye tseolytov Sybyry v proyzvodstve napytkov, Pyvo y napytky, 3, pp. 18-19.

13. Kornev V., Rybakov Yu., Chyrykov S. (2015), Sravnytelnaia otsenka strukturb chastyts y adsorbtsyonnыkh svoistv shunhyta y bentonyta, Vestnyk nauky y obrazovanyia, 9(11), pp. 20-23.

14. Shpileuski M. E., Shpileuski E. M., Stelmach V. F. (2001), Fullerenes and fullerene-like structures, Journal of engineering physics and thermophysics, 76(6), pp. 25-28.

15. Kuzmyn O. (2014), Usovershenstvovanye protsessov proyzvodstva alkoholnoi produktsyy, DonNUET, Donetsk.

16. Mosyn O. (2013), Perspektivy ispolzovaniya prirodnogo fullerensoderzhchego minerala shungita v vodopodgotovke, Voda $i$ vodoochisni tehnologii, 3(13), pp. 41-49.

17. Muhin V., Klushin V. (2012), Production and using of carbon adsorbents, RXTU, Moscow.

18. Wang S., Peng Y. (2010), Natural zeolites as effective adsorbents in water and wastewater treatment, Chemical Engineering Journal, 156(1), pp. 11-24.

19. Borisov B., Egorova E., Zaynullin R. (2014), Vodopodgotovka v proizvodstve pishchevykh produktov i napitkov, Professiya Publ, Sankt Petersburg.

20. Shrestha R., Joshi D. R., Gopali J. (2009), Oligodynamic fraction of silver, copper and brass on enteric bacteria isolated from water of Kathmandu Valley, Nepal Journal of Science and Technology, 10, pp. 189-193.

21. Moghazy El. (2011), Netraditsionnyye sposoby vodopodgotovki v proizvodstve syvorotochnykh napitkov, Tekhnika i tekhnologiya pishchevykh proizvodstv, 4, pp. 72-77.

22. Stounbjerg L., Vestergaard C., Andreasen B., Ipsen R. (2018), Beverage clouding agents: Review of principles and current manufacturing, Food Reviews International, 34(7), pp. 613-638. 
23. Kovalchuk V.P. (2005), Umovy zabezpechennya bysokoi yakosti likero-gorilchanyx napoiv na stadii vodopidgotovky. (2011), Xarchova i pererobna promyslovist, 11, pp. 24-27.

24. Kilcast D., Subramaniam P. (2011), Food and beverage stability and shelf lift, Woodhead Publishing Limited.

25. Novikov M. V., Kisterska L. D., Sadokhin V. V., Sadokhin V. P., Perevertailo V. M. (2012), Environmentally friendly technology: plasma sputtering of conductive materials and dispersion of nanoparticles in various liquids as one-step production cycle, Powder metallurgy and metal ceramics, 51(1-2), pp. 26-34. DOI: 10.1007/s11106-012-9392-7

26. Kisterska L., Loginova O., Sadokhyn V., Sadokhyn V. (2015), Innovatsiina tekhnolohiia vyrobnytstva biosumisnykh nanodezinfektantiv novoho pokolinnia, Visnyk NAN Ukrainy, 1, pp. 39-48.

27. UkrainetsA., Bolshak Yu., Marynin A. (2018), Okysno-vidnovnyy balans pytnoy vody pokaznyk yy yakosti ta fiziologichnoy povnoczinnosti, Harhova promyslovist, 24, pp. 6-14.

28. Particle Characterization: Light Scattering Methods (2002), Kluwer Academic Publishers New York, Boston, Dordrecht, London, Moscow, pp. 1-398: DOI DOI: 10.1007/0-30647124-8

29. Polyhalyna H, (2006), Analytycheskyi kontrol proyzvodstva vodok y lykerovodochnykh yzdelyi, DeLy prynt, Moscow

30. Koroliuk T., Usatiuk S., Kostinova T., Filipchenko I. (2017), Metodyka kontroliu kharchovykh produktiv, Kyiv, NUFT.

31. Abramova Y., Abramova Y., Medryshch M., Pavlenko S. (2013), Ynnovatsyy v sfere kontrolia kachestva alkoholnыkh napytkov, Spyrtnye napytky, 5, p. 52.

32. Schulz H., Fischer W. (2000), Comparison of Different Methods for Redox Potential Determination in Natural Waters, Redox fundamentals, Prosseses and Applications, pp. 42 54.

33. Bolshak Yu. (2015), Byolohycheskaia aktyvnost y zakonomernosty formyrovanyia bezreahentno modyfytsyrovannoi vody,. Knyha-plius, Kyiv.

34. Xiaorong Z, Haibo Li, Yinghua Li, Fei G, Zhongxin Ya. (2018), Int J Environ Res Public Health, Available at: http://10.3390/ijerph15122790

35. Copeland A, Darren A Lytle (2014), Measuring the oxidation-reduction potential of important oxidants in drinking water, Available at: DOI: 10.5942/jawwa.2014.106.0002.

36. Rahman S.M.E., Khan I. (2016), Comprehensive Reviews in Food Science and Food Safety, Available at: DOI: 10.1111/1541-4337.12200.

37. Sigg L. (2000), Redox Potential Measurement in Natural Waters: Significance, Concepts and Problems, Redox Fundamentals, Processes and Applications, pp. 1-12.

38. Cavchrina L. A., Koganovskiy A. M., Klimenko N. A., Topkin U. V. (2002), Adsorbciya fulvokyslot aktivnymy uglamy raznoy poristoy structury, Ximiya i texnologiya vody, 24(3), pp. 226-237.

39. Cheremisinoff N.P. (2002), Handbook of water and wastewater treatment technologies, Butterworth Heinemann-Pollution Engineering, Woburn.

40. Liudmyla Melnyk, Zynoviy Melnyk, Volodymyr Kryvorotko (2013), Methods of recovering schungite's adsorptive properties after processing red beet juice, Ukrainian Journal of Food Science, 1(2), pp. 223-227.

41. Liudmyla Melnyk, Olena Turchun, Natalia Tkachuk, Anatolii Kutz, Zynovii Melnyk (2014), Water-alcohol adsorbing cleaning out of higher alcohols by shungite, Ukrainian Journal of Food Science, 2(2), pp. 312-317. 